\title{
Identifying coaching skills to improve feedback use in postgraduate medical education
}

Citation for published version (APA):

Armson, H., Lockyer, J. M., Zetkulic, M., Koenings, K. D., \& Sargeant, J. (2019). Identifying coaching skills to improve feedback use in postgraduate medical education. Medical Education, 53(5), 477-493.

https://doi.org/10.1111/medu.13818

Document status and date:

Published: 01/05/2019

DOI:

10.1111/medu.13818

Document Version:

Publisher's PDF, also known as Version of record

Document license:

Taverne

Please check the document version of this publication:

- A submitted manuscript is the version of the article upon submission and before peer-review. There can be important differences between the submitted version and the official published version of record.

People interested in the research are advised to contact the author for the final version of the publication, or visit the DOI to the publisher's website.

- The final author version and the galley proof are versions of the publication after peer review.

- The final published version features the final layout of the paper including the volume, issue and page numbers.

Link to publication

\footnotetext{
General rights rights.

- You may freely distribute the URL identifying the publication in the public portal. please follow below link for the End User Agreement:

www.umlib.nl/taverne-license

Take down policy

If you believe that this document breaches copyright please contact us at:

repository@maastrichtuniversity.nl

providing details and we will investigate your claim.
}

Copyright and moral rights for the publications made accessible in the public portal are retained by the authors and/or other copyright owners and it is a condition of accessing publications that users recognise and abide by the legal requirements associated with these

- Users may download and print one copy of any publication from the public portal for the purpose of private study or research.

- You may not further distribute the material or use it for any profit-making activity or commercial gain

If the publication is distributed under the terms of Article $25 \mathrm{fa}$ of the Dutch Copyright Act, indicated by the "Taverne" license above, 


\title{
Identifying coaching skills to improve feedback use in postgraduate medical education
}

\author{
Heather Armson, ${ }^{1}$ (D) Jocelyn M Lockyer, ${ }^{2}$ Marygrace Zetkulic, ${ }^{3}$ Karen D Könings ${ }^{4}$ \& Joan Sargeant ${ }^{5}$
}

OBJECTIVES Coaching in medical education has recently gained prominence, but minimal attention has been given to key skills and determining how they work to effectively ensure residents are progressing and developing self-assessment skills. This study examined process-oriented and contentoriented coaching skills used in coaching sessions, with particular attention to how supervisors use them to enhance resident acceptance of feedback to enhance learning.

METHODS This qualitative study analysed secondary audiotaped data from 15 supervisors: resident dyads during two feedback sessions, 4 months apart. The R2C2 model was used to engage the resident, build a relationship, explore reactions to feedback, explore resident perceptions of content, and coach for change. Framework analysis was used, including familiarisation with the data, identifying the thematic framework, indexing and charting the data and mapping and interpretation.

RESULTS Process skills included preparation, relationship development, using micro communication skills and techniques to promote reflection and self-assessment by the resident and supervisor flexibility. Content skills related to the specific feedback content included engaging the resident in discussion, ensuring the discussion was collaborative and focused on goal setting, co-developing a Learning Change Plan, ensuring resident commitment and following up on the plan. Together, these skills foster agency in the resident learner. Three overarching themes emerged from the analysis: the interconnectedness of process and content; tensions between encouraging self-direction and ensuring progress and competence; and balancing a coaching dialogue and a teaching monologue.

CONCLUSIONS Effective coaching by supervisors requires a combination of specific process and content skills that are chosen depending on the needs of the individual resident. Mastering these skills helps residents engage and develop agency in their own professional development. These outcomes depend on faculty maintaining a balance between coaching and teaching, encouraging resident self-direction and ensuring progression to competence.

\footnotetext{
${ }^{1}$ Department of Family Medicine, University of Calgary, Calgary, Alberta, Canada

${ }^{2}$ Department of Community Health Sciences, University of Calgary, Calgary, Alberta, Canada

${ }^{3}$ Department of Medicine, Hackensack University Hospital, Hackensack, New Jersey, USA

${ }^{4}$ Department of Educational Development \& Research and School of Health Professions Education, Maastricht University,

Maastricht, the Netherlands
}

\footnotetext{
${ }^{5}$ Continuing Medical Education and Division of Medical Education, Dalhousie University, Halifax, Nova Scotia, Canada

Correspondence: Heather Armson, Sunridge Family Medicine Teaching Centre, 268536 Street, N.E., Calgary, Alberta, T1Y 5S3, Canada. Tel: 001403943 5000; E-mail: armson@ucalgary.ca
} 


\section{INTRODUCTION}

Coaching has gained prominence in medical education as residency supervisors seek ways to improve the effectiveness of feedback for performance improvement, particularly in the context of competency-based medical education (CBME).${ }^{1-4}$ Coaching moves a step beyond providing feedback and focuses upon identifying performance goals in response to feedback and developing plans to address them. To date, coaching has been particularly effective in improving technical skills. ${ }^{5,6}$ There is also evidence that coaching supports non-technical skills and improves physician well-being. ${ }^{4,7}$ This study focuses on the skills supervisors need to effectively coach residents in medical education settings.

Professional coaching has its roots in competitive sports and music and recently has been adopted increasingly in the business and corporate worlds. ${ }^{4}$ Coaching in sports and music endorses a model for performance improvement and development based upon direct observation of the learner's performance followed by an individual feedback discussion about what is being done well, defining performance gaps and developing strategies to improve..$^{9}$ Medical education may aspire to create a similar process and outcome but is constrained by a number of factors. Longitudinal relationships built on trust that facilitate a dialogue based on accurate, in-depth knowledge of the learner are frequently lacking in medical education settings, preventing the more directive and constructive feedback seen in other coaching settings. ${ }^{9-12}$ Other barriers in medical education, when compared with sport or music settings, that impair productive coaching conversations, including the lack of a continuous improvement stance focused on working towards full potential; $;^{4,9,13,14}$ the perceived need to maintain a comfortable relationship; ${ }^{12}$ and the use of vague language to save face. ${ }^{15}$ Other research identifies internal factors within the medical learner that negatively influence their willingness to engage in feedback and performance conversations, such as skepticism about the process, their wish to appear competent and the possible conflict with their own self-assessment. ${ }^{16-19}$

Competency-based medical education, with its focus on observation, feedback and resident progression, draws attention to these challenges. It obliges us to seek ways to address barriers and promote productive feedback conversations that support resident development. Hence, coaching is being adopted as a promising strategy. Although there is no universal consensus on the definition of coaching in education, the definition suggested by van Nieuwerburgh ${ }^{20}$ appears to capture the crucial components. He identifies coaching as

a one-to-one conversation focused on the enhancement of learning and development through increasing self-awareness and a sense of personal responsibility, where the coach facilitates the self-directed learning of the coachee through questioning, active listening, and appropriate challenge in a supportive and encouraging climate. ${ }^{20}$ (p.17)

The aim is to support sustainable change in behaviours or ways of thinking and focus on learning and development. ${ }^{21}$ Notably, feedback is an important component of coaching and is 'given with the intent to improve the trainee's performance' (p.193). ${ }^{22}$ Feedback can be defined as:

a process whereby learners obtain information about their work in order to appreciate the similarities and differences between the appropriate standards for any given work, and the qualities of the work itself, in order to generate improved work. ${ }^{23}$

Thus, coaching is predicated on accurate feedback but pushes the conversation beyond intention to action to improve performance. However, the specific skills involved in coaching in education, particularly medical education, remain unclear.

Prior to this study, we undertook a thorough review of the coaching in education literature and identified and compiled a comprehensive list of coaching skills through iterative analysis and synthesis of the various models. The team members had several discussions around the categorisation of the coaching skills as they reviewed the literature and analysed the data iteratively. Although coaching in education is described as a set of specific skills or actions, ${ }^{20}$ some actions appear to be part of a more generic coaching 'process', including structure, approaches and skill development whereas others specifically address management of the 'content' or subject matter of the coaching session including ensuring the clear delivery and establishing a common understanding of the actual data used in the discussion. (Table 1). 
Table 1 Framework for process- and content-oriented skills stemming from literature review

\begin{tabular}{|c|c|}
\hline Process skills & Content skills \\
\hline $\begin{array}{l}\text { Preparation of the coach: } \\
\text { coach is familiar with } \\
\text { context and content of the } \\
\text { assessment }{ }^{13,47,49,50}\end{array}$ & $\begin{array}{l}\text { Feedback: coach provides } \\
\text { feedback about performance } \\
\text { and engages learner in } \\
\text { discussion }{ }^{14,51,52,53}\end{array}$ \\
\hline $\begin{array}{l}\text { Preparation of the resident: } \\
\text { coach outlines } \\
\text { expectations }{ }^{5,9,41,42} \text { and } \\
\text { establishes credibility }{ }^{53,54}\end{array}$ & $\begin{array}{l}\text { Collaborative discussion: } \\
\text { coach and learner collaborate } \\
\text { in the identification of } \\
\text { priority performance gaps } \\
\text { and areas for } \\
\text { improvement }^{14,53,55}\end{array}$ \\
\hline $\begin{array}{l}\text { Relationship development: } \\
\text { coach develops and } \\
\text { continues to build the } \\
\text { relationship throughout } \\
\text { the coaching } \\
\text { session, }{ }^{14,56,57} \text { promoting } \\
\text { safety for residents to } \\
\text { share reactions and self- } \\
\text { assessment }^{58}\end{array}$ & $\begin{array}{l}\text { Collaborative focus on goal } \\
\text { setting: coach and learner } \\
\text { collaborate to develop the } \\
\text { outcomes and changes to be } \\
\text { achieved }^{7,41,42,54,59-61}\end{array}$ \\
\hline $\begin{array}{l}\text { Uses communication micro } \\
\text { skills to explore reactions, } \\
\text { clarify understanding and } \\
\text { provide encouragement } \\
\text { through active listening }{ }^{33} \\
\text { and open } \\
\text { questioning } \\
33,41,59,62\end{array}$ & 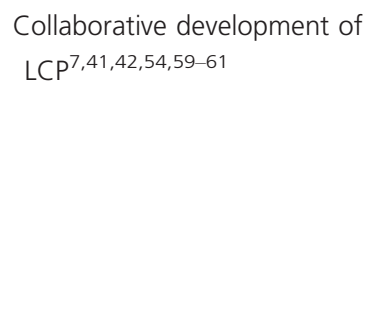 \\
\hline $\begin{array}{l}\text { Promote reflection and self- } \\
\text { assessment: through use } \\
\text { of micro skills and } \\
\text { 'constructively bringing } \\
\text { blind spots into focus' } \\
\text { (13 pg.1037) }\end{array}$ & $\begin{array}{l}\text { Ensure learner commitment: } \\
\text { coach ensures that LCP } \\
\text { developed is viable and } \\
\text { learner is committed to } \\
\text { following it }\end{array}$ \\
\hline $\begin{array}{l}\text { Flexibility: coach is flexible } \\
\text { in content to be } \\
\text { discussed }^{65}\end{array}$ & $\begin{array}{l}\text { Follow-up: coach ensures the } \\
\text { LCP has been achieved } \\
\text { through monitoring and } \\
\text { learner accountability }{ }^{7,41,54}\end{array}$ \\
\hline
\end{tabular}

To understand how these skills are used in the context of postgraduate medical education, we reviewed data from our earlier international study that applied an evidence- and theory-based feedback and coaching model in residency education and assessment, the R2C2 (relationship, reactions, content, coaching) model. ${ }^{24}$ Competency-based medical education relies on learners receiving regular feedback to enable them to progress through various milestones to achieve competency. ${ }^{25-27}$ However, residents continue to report receiving infrequent and suboptimal feedback, which diminishes its usefulness and reduces the resident's motivation and ability to improve. The R2C2 model was developed to address these issues and to enhance acceptance and use of the feedback provided. The model includes four phases: (i) relationship building; (ii) exploring reactions to feedback; (iii) exploring understanding of feedback content, and (iv) coaching for change including development of a Learning Change Plan (LCP). Its development was founded upon three bodies of theory and research, which provide the guidance and sensitising concepts for R2C2 use and its evaluation. These include humanism and learner-centredness, informed self-assessment, and the science of behaviour change. ${ }^{3}$ Results of the study in residency education ${ }^{24}$ showed the model was effective in engaging residents in a reflective, goal-oriented discussion about performance data, supporting coaching and enabling collaborative development of a change plan. However, at that time, we did not perform an in-depth analysis for the specific skills of coaching, as identified in the literature and highlighted in Table 1.

The current study reanalyses the data from the coaching phase to determine supervisor use of the critical skills for effective coaching identified from the literature review. The goal of our study was to understand supervisors' use of the identified coaching skills in their feedback sessions with residents. Specific research questions included:

1 Which specific process- and content-oriented skills did supervisors use?

2 How did they use them?

3 How is each skill best described and exemplified?

\section{METHODS}

\section{Study design}

This qualitative study focused on secondary analysis of data from the Sargeant et al. ${ }^{24}$ study. All authors (HA, JML, MGZ, KDK and JS) were involved in all aspects of the original study including recruitment, 
analysis, assessment and interpretation. In that study, dyads of supervisors and residents were recruited from five diverse postgraduate medical education programmes in Canada, USA and the Netherlands: (i) anesthesia; (ii) family medicine; (iii) internal medicine; (iv) orthopedics, and (v) psychiatry. Supervisors who were faculty members and would normally conduct assessment and feedback meetings with the respective resident were recruited from each programme through the programme directors. In most situations, the supervisor and resident were known to each other, though in a few instances the supervisor and resident had not met prior to the initial conversation. Residents were recruited through presentations at regular teaching sessions and meetings.

Each supervisor was trained in using the model prior to their first session, including being provided examples of specific phrases to promote a coaching approach. The sessions occurred during the regular programme assessment meetings. Prior to the feedback and coaching meeting, each supervisor had usual progress data related to the residents' performance (e.g. daily encounter forms, in-training evaluations) except for one of the programmes in which the supervisors observed a long objective structured clinical examination prior to providing feedback and coaching.

Each dyad met for two feedback sessions several months apart and participated separately in debrief interviews after each session. Sessions and debrief interviews were audiotaped and transcribed. A total of 40 residents and 17 supervisors participated in the study.

For the current analysis, we selected three dyads from each of the five programmes and examined data from the feedback sessions. The dyads were purposively selected to represent residents at different levels of performance and included those who appeared to be performing at the expected level for their stage of training and those who appeared to be struggling with one or more performance issues. To select them, the feedback transcripts were reviewed by the research team members at each site to identify those residents who appeared to be excelling and those who appeared to be more challenged.

\section{Data analysis}

We analysed the feedback session transcript data using the Framework Analysis (FA) method initially described by Ritchie and Spencer ${ }^{28}$ and elaborated on by others. ${ }^{29-31}$ Framework Analysis was chosen as an appropriate method for analysis of data based on a framework derived from the pre-existing literature. Framework Analysis provides a systematic approach to thematic analysis of the data set through comparison within and across the data to identify common and divergent aspects. The contextual elements of the data are maintained before focusing on relationships between different parts of the data thereby facilitating descriptive and explanatory conclusions to shed light on the study questions. We used standard qualitative procedures for ensuring the rigour and trustworthiness of analysis procedures and results. ${ }^{32,33}$ These included the pairing of team members to analyse each transcript and discussion of their interpretations and findings with each other and then the larger team. At each level of analysis, differences were identified and resolved through discussion and by returning to the data if required. Summaries were shared and critical discussions of findings occurred with the whole team. To minimise bias, team members who were responsible for assessment of residents in their respective site, did not analyse transcripts from their own site. Team members were also encouraged to be reflective and reflexive throughout.

We followed the five-stage FA process involving:

\section{Familiarisation}

The authors (HA, JML, MGZ, KDK and JS) were familiar with the transcribed feedback session data, having read through each of the transcripts at least once and often several times. Four of the authors (HA, JML, JS, MGZ) each reviewed the transcribed feedback sessions for seven to eight dyads, looking for examples of evidence of use of process- and content-oriented coaching skills as described in the literature and set out in Table 1.

\section{Identifying a thematic framework}

After reviewing the data from Stage 1, further discussion affirmed the appropriateness of the proposed framework of process- and contentoriented coaching skills for this analysis.

\section{Indexing}

Each of the four authors (HA, JML, JS and MGZ) entered data into the framework and considered whether further categories were needed. The data was compiled into a Microsoft ${ }^{\circledR}$ Excel spreadsheet 
(Microsoft Corp., Redmond, WA, USA) for review within and across dyads. A constant comparative approach was used to review data across the matrix.

\section{Charting}

Working in pairs, we created summaries from the spreadsheets for each of the process and content categories that described how each of the skills appeared to function, along with examples of when these skills were optimally used and when utilisation was less successful.

\section{Mapping and interpretation}

Through iterative discussion of the process- and content-oriented skills identified, we were able to explore the data further and identify new overarching themes, reach consensus, compare our work with other descriptions of coaching and identify unique aspects of coaching in the medical setting.

\section{RESULTS}

The presentation of the results begins with a description of the participants followed by the findings of the 'Indexing' and 'Charting' stages of analysis, i.e. the descriptions of the individual coaching skills, and second, findings of the 'Mapping and Interpretation' stage in which we identified overarching themes that emerged from the data.

\section{Demographics}

Participants included 15 dyads of supervisors and residents (three from each site). There was a mix of male and female residents from R2 (Second year resident) to $\mathrm{R} 5$ and both male and female supervisors. Having graduated from medical school between 1982 and 2001, supervisors had a range of medical experience and were experienced in giving formal feedback to residents, which they provided at least four times each year.

\section{Indexing and charting}

The first level of analysis focused on skills included in each of the process- and content-oriented categories and ensuring no additional skills were described. Process- and content-oriented skills are set out in Tables 2 and 3, respectively. The tables provide brief descriptions of each coaching skill derived from both the literature and the data analysis. The tables also provide, from the data for each skill, an exemplar quote of effective use of each skill and describe less effective skill use, the latter often demonstrated by being absent. The following paragraphs provide an overview of how the skills were used.

\section{Process-oriented skills}

For process-oriented skills, examples of effective supervisor preparation for the coaching session included review of the residents' assessment reports and understanding the residents' progress relative to expectations for their training level. Awareness of the LCP and follow-up in subsequent sessions were also important; however, there was variable attention to this aspect. Most supervisors appeared familiar with the assessment data, but some were less aware of the resident context and the importance of the LCP.

This lack of context for the discussion was more marked in examining the preparation of the learner. Residents often seemed confused or unaware of the shift to a coaching model and the expectations this placed on their contribution to the process. On the other hand, some coaches outlined both the purpose and process of the coaching session and stressed the importance of the LCP.

All supervisors demonstrated effective building and maintaining of positive and respectful learning relationships. Some supervisors had previous relationships with residents that appeared to enhance the discussion based on the knowledge acquired outside of the coaching session. However, in dyads without previous contact, supervisors were able to establish a successful relationship focused on continual improvement.

Supervisors provided numerous examples demonstrating effective use of learner-centered facilitative approaches, or micro skills, ${ }^{34}$ such as eliciting residents' reactions to their assessment reports, listening attentively to the resident, using open questions to ensure understanding and promoting reflection and self-critique (Table 4). Some demonstrated effective use of these techniques throughout all phases of the session, and they continued to use these techniques effectively for residents experiencing challenges.

Some supervisors used more directive approaches for residents who appeared to lack insight. More 
Table 2 Process-oriented coaching skills identified in the study

\begin{tabular}{|c|c|c|c|}
\hline Skill & $\begin{array}{l}\text { Description of skill used } \\
\text { effectively }\end{array}$ & $\begin{array}{l}\text { Description of skill used less } \\
\text { effectively }\end{array}$ & Exemplar quotations \\
\hline $\begin{array}{l}\text { Preparation of } \\
\text { the coach }\end{array}$ & $\begin{array}{l}\text { Coach: } \\
\text { - understands the workplace } \\
\text { context and expectations } \\
\text { - seamlessly identifies data } \\
\text { that is relevant to the } \\
\text { discussion } \\
\text { - identifies the information } \\
\text { that is critical for the } \\
\text { trainee's development } \\
\text { - asks about successful } \\
\text { completion of previous } \\
\text { goals (Time 2) }\end{array}$ & $\begin{array}{l}\text { Coach: } \\
\text { - is unfamiliar with the } \\
\text { assessment material, the } \\
\text { expectations of the rotations } \\
\text { or the need to complete a } \\
\text { LCP }\end{array}$ & $\begin{array}{l}\text { Supervisor: Okay. So those are good solid } \\
\text { rotations because they need a lot of } \\
\text { responsibility. In [department], it's also } \\
\text { helpful because you have a lot of direct } \\
\text { supervision because the attendings are } \\
\text { almost always there. (C R4, S1) } \\
\text { Supervisor: Good. Good. Well, as you know, } \\
\text { as your academic advisor, I need to do a } \\
\text { quarterly review of your progress and it's } \\
\text { nice that we can get together and talk about } \\
\text { it. Now, you have already seen it. } \\
\text { Resident: Yes. } \\
\text { Supervisor: But I did bring a copy with us so } \\
\text { we can review it. So, I think that's basically } \\
\text { what we'll do, is we'll just sort of go through } \\
\text { and talk about the evaluation and see how } \\
\text { you feel about it and then see if there are } \\
\text { some things we can improve and focus on } \\
\text { afterwards. (D, R1, S3) }\end{array}$ \\
\hline $\begin{array}{l}\text { Preparation of } \\
\text { the resident } \\
\text { (learner) }\end{array}$ & $\begin{array}{l}\text { Coach: } \\
\text { - clarifies the purpose for the } \\
\text { coaching session } \\
\text { - explores the R2C2 } \\
\text { model with the resident, } \\
\text { including ensuring } \\
\text { understanding of what } \\
\text { needs to be accomplished } \\
\text { by the end of the } \\
\text { discussion including the } \\
\text { expectation that a LCP will } \\
\text { be completed and } \\
\text { reviewed at the next } \\
\text { session }\end{array}$ & $\begin{array}{l}\text { Coach: } \\
\text { - does not explain what will } \\
\text { happen or the objectives for } \\
\text { the session. At Time 2, does } \\
\text { not retrieve LCP or follow-up } \\
\text { on what had been agreed } \\
\text { upon previously }\end{array}$ & $\begin{array}{l}\text { Supervisor: This is a Learning Change Plan. } \\
\text { We're going to come up with real specific } \\
\text { things that you're going to do over the next } \\
6 \text { months to get you to a higher level. In } \\
\text { terms of first off, I'd like to see you work } \\
\text { more as a resident in [department] more } \\
\text { than as an intern. That means coming up } \\
\text { with your assessments on [department] } \\
\text { admissions and coming up with the } \\
\text { management plans. I think you do it already, } \\
\text { even though it's not necessarily what's } \\
\text { expected of you. Now I'm expecting it of } \\
\text { you. (C, R4, S1) }\end{array}$ \\
\hline $\begin{array}{l}\text { Relationship } \\
\text { development }\end{array}$ & $\begin{array}{l}\text { Coach: } \\
\text { - asks resident to articulate } \\
\text { their understanding of } \\
\text { feedback } \\
\text { - enhances engagement } \\
\text { through identifying current } \\
\text { residency experiences } \\
\text { - if present, builds upon } \\
\text { previous relationship } \\
\text { - explores resident context } \\
\text { through enquiry and the }\end{array}$ & $\begin{array}{l}\text { Coach: } \\
\text { - omits this or presents a } \\
\text { formulaic approach that } \\
\text { appears forced and insincere }\end{array}$ & $\begin{array}{l}\text { Supervisor: And yet at the same time, this } \\
\text { other stuff with the current rotation is } \\
\text { occurring right now in real-time so ... So } \\
\text { how are you doing with all that? } \\
\text { Resident: So as far as the real-time stuff? } \\
\text { Supervisor: The real-time stuff. } \\
\text { Resident: So I at least slept last night. So, I } \\
\text { had a nice } 72 \text { hours where I slept } 7 \text {. So, I } \\
\text { was in pretty rough shape yesterday. } \\
\text { Supervisor: Could you sleep two nights ago } \\
\text { after we talked on the phone? }\end{array}$ \\
\hline
\end{tabular}


Table 2 (Continued)

\begin{tabular}{|c|c|c|c|}
\hline Skill & $\begin{array}{l}\text { Description of skill used } \\
\text { effectively }\end{array}$ & $\begin{array}{l}\text { Description of skill used less } \\
\text { effectively }\end{array}$ & Exemplar quotations \\
\hline & $\begin{array}{l}\text { use of active listening } \\
\text { - builds trust through } \\
\text { clarifying and validating } \\
\text { information, experiences } \\
\text { and feelings } \\
\text { - may ask about coping and } \\
\text { life stressors, family and } \\
\text { support systems, if } \\
\text { appropriate, and part of } \\
\text { the educational culture }\end{array}$ & & $\begin{array}{l}\text { Resident: Oh poorly. Nice and poorly. But it } \\
\text { helped. I mean it was ... I would have } \\
\text { probably been worse otherwise. (A, R5, S4) }\end{array}$ \\
\hline $\begin{array}{l}\text { Explore } \\
\text { reactions, } \\
\text { clarify } \\
\text { understanding } \\
\text { and provide } \\
\text { encouragement } \\
\text { (micro skills) }\end{array}$ & $\begin{array}{l}\text { Coach: } \\
\text { - offers encouragement and } \\
\text { support through active } \\
\text { listening and reinforcement } \\
\text { of good performance } \\
\text { - is responsive to resident } \\
\text { concerns } \\
\text { - explores the resident's } \\
\text { interpretation of their } \\
\text { experiences and asks for } \\
\text { further explanations } \\
\text { - summarises content with } \\
\text { additional analysis }\end{array}$ & $\begin{array}{l}\text { Coach: } \\
\text { - talks for majority of the time } \\
\text { - is overly directive preventing } \\
\text { the development of a } \\
\text { collaborative discussion } \\
\text { - does not recognise or respond } \\
\text { to resident's comments and } \\
\text { persists with own agenda }\end{array}$ & $\begin{array}{l}\text { Supervisor: You're right. So, you saw the data } \\
\text { on your evaluations and stuff. } \\
\text { Resident: Yes. } \\
\text { Supervisor: What do you think? You should } \\
\text { be happy. } \\
\text { Resident: I was pretty happy with it. Yes. I } \\
\text { think it was pretty ... I mean it's always ... the } \\
\text { truth is I mean I think I second-guess myself a } \\
\text { fair amount with certain things just because I } \\
\text { think I'm fairly personable and able to cover } \\
\text { for some knowledge deficiencies with, you } \\
\text { know, talking my way through things. I think } \\
\text { that applies both with the patients and to } \\
\text { preceptors [laughs] and stuff. That being said, } \\
\text { I think that still counts as a skill. [laughs] And I } \\
\text { think that I am getting more comfortable with } \\
\text { my knowledge base either way. (A, R5, S4) }\end{array}$ \\
\hline $\begin{array}{l}\text { Promote } \\
\text { reflection and } \\
\text { self-assessment }\end{array}$ & $\begin{array}{l}\text { Coach: } \\
\text { - uses open questions to } \\
\text { stimulate reflection } \\
\text { - employs extensive } \\
\text { clarification of thinking to } \\
\text { promote development of } \\
\text { understanding through } \\
\text { encouraging reflection } \\
\text { - encourages consideration } \\
\text { of next steps }\end{array}$ & $\begin{array}{l}\text { Coach: } \\
\text { - does not ask open questions } \\
\text { - provides feedback without } \\
\text { space for reflection } \\
\text { - promotes their agenda } \\
\text { including advice giving }\end{array}$ & $\begin{array}{l}\text { Supervisor: Obviously you're doing it really well. } \\
\text { Are there any things that you might want to } \\
\text { continue or consider to do so you can do that } \\
\text { more often? Or things that will help you to } \\
\text { refine that as you move forward? } \\
\text { Resident: I think it's just a matter of kind of } \\
\text { like being conscious of that. And before, I ... } \\
\text { Like as soon as I see the complaint I ... or the } \\
\text { presentation, I just kind of mentally take 5, } \\
10 \text { seconds to just kind of think about what } \\
\text { could potentially be a cause and kind of my } \\
\text { general approach to that presentation. } \\
\text { Supervisor: Mhm. } \\
\text { Resident: And every time I do that, it just } \\
\text { provides a nice framework. And then } \\
\text { efficiency and everything kind of follows after } \\
\text { that. So, I think it's just being conscious of it }\end{array}$ \\
\hline
\end{tabular}


Table 2 (Continued)

\begin{tabular}{|c|c|c|c|}
\hline Skill & $\begin{array}{l}\text { Description of skill used } \\
\text { effectively }\end{array}$ & $\begin{array}{l}\text { Description of skill used less } \\
\text { effectively }\end{array}$ & Exemplar quotations \\
\hline Flexibility & $\begin{array}{l}\text { Coach: } \\
\text { - identifies when the } \\
\text { resident can lead the } \\
\text { discussion or when more } \\
\text { guidance is required } \\
\text { - is able to re-focus the } \\
\text { discussion in light of } \\
\text { information that needs to } \\
\text { be immediately addressed } \\
\text { (e.g. data reveals a } \\
\text { surprise) }\end{array}$ & $\begin{array}{l}\text { Coach and resident: } \\
\text { - enable discussion to be } \\
\text { directed by either the coach or } \\
\text { the resident, depending on } \\
\text { need } \\
\text { - Caution: If it is driven by the } \\
\text { coach, it is difficult to } \\
\text { determine whether resident is } \\
\text { accepting the information and } \\
\text { interpretation or simply } \\
\text { acquiescing } \\
\text { - Caution: If exclusively resident } \\
\text { driven, coach may not be } \\
\text { ensuring resident is meeting } \\
\text { EPAs and milestones or } \\
\text { attending to patient safety issues }\end{array}$ & $\begin{array}{l}\text { and making it a habit. And I think it's just a } \\
\text { matter of becoming a habit. (A, R3, S2) } \\
\text { Time 1: Responds to residents change in } \\
\text { direction and has advice to offer to address } \\
\text { concern } \\
\text { Time 2: Encourages the resident to establish } \\
\text { the areas of discussion ( } A, R 5, S 4) \\
\text { Time 1: Supervisor sets the agenda but listens } \\
\text { to the resident approaches } \\
\text { Time 2: Supervisor responds to issue raised } \\
\text { by resident of not much change in } \\
\text { evaluations (D, R1, S3) }\end{array}$ \\
\hline
\end{tabular}

EPA, Entrustable Professional Activities; LCP, Learning Change Plan; R2C2, relationship, reaction, content, coaching, $C=$ location; R4 = resident 4; S1 = supervisor 1 .

directive rather than facilitative coaching techniques included asking more close-ended questions, spending more time speaking than listening and being more directive than facilitative. It also meant taking more leadership in completion of the LCP, whether written or only oral, for the resident.

Finally, flexibility was a process skill displayed by only a few supervisors in response to resident needs. Flexibility around content was demonstrated in two settings where unexpected assessments triggered a strong emotional response, which required a more intensive, focused approach. In both cases, the supervisors were responsive to the acute needs of the resident, explicitly setting aside other potential goals for exploration until these emergent priorities had been resolved. Flexibility was also noted around decisions as to whether the supervisor needed to become more directive in the conversation to ensure gaps in competency were identified and addressed. Inflexible application of coaching also impacted effectiveness, especially if the aims of the coaching session were not explicitly discussed as part of preparing the resident for the discussion.

\section{Content-oriented skills}

Content-oriented skills included developing a common understanding of the meaning of the assessment and feedback data, collaborative prioritisation of areas for improvement and codevelopment of an LCP. Supervisors were able to explore the feedback provided and engage the resident in a discussion about their understanding and acceptance. Some supervisors struggled when residents appeared resistant to feedback data and some reverted to more didactic explanations of the data, as noted above.

Discussion of the feedback needed to be followed by identifying gaps and potential areas for improvement if growth was to occur. Some residents were able to engage in a collaborative discussion to identify goals. Other conversations led to supervisors identifying goals and approaches for improvement, often without space for resident input. This was most noticeable for the few supervisors who appeared less skilled in using communication micro skills. (Table 4) 
Table 3 Content-oriented coaching skills identified in the study

\begin{tabular}{|c|c|c|c|}
\hline Skill & $\begin{array}{l}\text { Description of skill used } \\
\text { effectively }\end{array}$ & $\begin{array}{l}\text { Description of skill } \\
\text { used less effectively }\end{array}$ & Exemplar quotations \\
\hline $\begin{array}{l}\text { Feedback about } \\
\text { performance } \\
\text { and engage } \\
\text { resident in } \\
\text { discussion }\end{array}$ & $\begin{array}{l}\text { Coach: } \\
\text { - engages the resident in } \\
\text { a discussion about the } \\
\text { specific data in the } \\
\text { assessment report(s) } \\
\text { and what it means to } \\
\text { the trainee to ensure } \\
\text { they have the same } \\
\text { understanding of the } \\
\text { data } \\
\text { - queries what the } \\
\text { trainee plans as next } \\
\text { steps }\end{array}$ & $\begin{array}{l}\text { Coach: } \\
\text { - is unable to engage } \\
\text { resident in } \\
\text { discussion, possibly } \\
\text { due to resident } \\
\text { resistance or } \\
\text { coaches' approach } \\
\text { to questioning }\end{array}$ & $\begin{array}{l}\text { Supervisor: Very, very impressive. All right. So, the field } \\
\text { notes and what I saw, as we mentioned last time, pretty } \\
\text { impressive and continue to just roll by leaps and bounds. } \\
\text { But feedback's always an opportunity to improve or reflect } \\
\text { on what you're seeing and feeling and thinking and also } \\
\text { the responses from field notes and ITERs and things. So is } \\
\text { there any of the feedback that particularly resonated with } \\
\text { you or ... " (A, R3, S2) } \\
\text { Supervisor: But what do you mean then? } \\
\text { Resident: Yes, I can flood people with too much } \\
\text { information, and then I go quite fast and then the tempo } \\
\text { has to be lower and ... } \\
\text { Supervisor: So that is something you got back and it didn't } \\
\text { amaze you, it was something you recognise? Time } 2 \text { : } \\
\text { Supervisor: and what do you need to do to achieve that? } \\
\text { (B, R1, S1/2) }\end{array}$ \\
\hline $\begin{array}{l}\text { Collaboratively } \\
\text { identify priority } \\
\text { performance } \\
\text { gaps and areas } \\
\text { for improvement }\end{array}$ & $\begin{array}{l}\text { Coach: } \\
\text { - draws on the } \\
\text { assessment report to } \\
\text { help the resident } \\
\text { identify the gaps and } \\
\text { priority areas } \\
\text { - may push resident out } \\
\text { of comfort zone } \\
\text { - may be more directive } \\
\text { where a trainee lacks } \\
\text { insight }\end{array}$ & $\begin{array}{l}\text { Coach: } \\
\text { - identifies the goals } \\
\text { and trainee } \\
\text { acquiesces or does } \\
\text { not respond } \\
\text { - continues the } \\
\text { conversation } \\
\text { without attention to } \\
\text { resident lack of } \\
\text { engagement }\end{array}$ & $\begin{array}{l}\text { Resident: I mean they're obviously supposed to be quite } \\
\text { specific. So maybe the IUD insertions. Is that too specific? } \\
\text { Supervisor: No. No. } \\
\text { Resident: Or is that ... } \\
\text { Supervisor: I think you have to be specific. Because one of } \\
\text { your areas was procedures. } \\
\text { Resident: Yes. } \\
\text { Supervisor: And I think the other one was to be intentional } \\
\text { before you went into ... } \\
\text { Resident: Mhm. } \\
\text { Supervisor: the room. So, if those are the two that we } \\
\text { want to focus on. } \\
\text { Resident: Yes. } \\
\text { Supervisor: Because this is ... really the purpose is, and I } \\
\text { already mentioned this to you, to take all this information } \\
\text { and get even better. (C R3 S2) }\end{array}$ \\
\hline $\begin{array}{l}\text { Collaboratively } \\
\text { focus on goal } \\
\text { setting }\end{array}$ & $\begin{array}{l}\text { Coach and resident: } \\
\text { - identifies the specific } \\
\text { change or outcome } \\
\text { they wish to achieve } \\
\text { related to the identified } \\
\text { gap }\end{array}$ & $\begin{array}{l}\text { Coach and resident: } \\
\text { - do not set specific } \\
\text { goals that can be } \\
\text { monitored or easily } \\
\text { assessed for } \\
\text { progress on follow- } \\
\text { up or during the } \\
\text { next rotation }\end{array}$ & $\begin{array}{l}\text { Resident: There's another thing, I would be happy ... } \\
\text { Supervisor: Mhm. } \\
\text { Resident: with myself if I can get my speed up on an } \\
\text { admission. Like that's like a huge goal for me. } \\
\text { Supervisor: Okay. Well, actually you're going to have plenty of } \\
\text { opportunity. So, let's put for another one in terms of ... Okay } \\
\text { improve efficiency on admitting patients. [pause] And I'm going } \\
\text { to add here without diminishing quality. You don't want to } \\
\text { improve efficiency at the expense of quality. (C R7 S1) } \\
\text { Time 1: R3: I think the first thing is interrupt... how to interrupt } \\
\text { people. } \\
\text { S3: Okay. }\end{array}$ \\
\hline
\end{tabular}


Table 3 (Continued)

\begin{tabular}{|c|c|c|c|}
\hline Skill & $\begin{array}{l}\text { Description of skill used } \\
\text { effectively }\end{array}$ & $\begin{array}{l}\text { Description of skill } \\
\text { used less effectively }\end{array}$ & Exemplar quotations \\
\hline & & & $\begin{array}{l}\text { R3: Like working on different ways of interrupting people, } \\
\text { based on the feedback so ... } \\
\text { S3: All right. So, go ahead and jot that down. } \\
\text { R3: Okay. } \\
\text { S3: [pause] When do you want to start this? } \\
\text { R3: I guess next time I see a patient. } \\
\text { S3: Okay. So probably next week. } \\
\text { R3: Yes. Or I could start in my personal life, start interrupting } \\
\text { my friends [laughter] and see how that goes. (TR3 S3) }\end{array}$ \\
\hline $\begin{array}{l}\text { Collaboratively } \\
\text { develop LCP }\end{array}$ & $\begin{array}{l}\text { Coach and resident: } \\
\text { - follow the steps to } \\
\text { create the LCP with clear } \\
\text { articulation of how } \\
\text { implementation will } \\
\text { proceed and how } \\
\text { resident will know that } \\
\text { change has been } \\
\text { achieved } \\
\text { - write down plan so it can } \\
\text { be retrieved for the next } \\
\text { session }\end{array}$ & $\begin{array}{l}\text { Coach and resident: } \\
\text { - make partial or no } \\
\text { use of the LCP. No } \\
\text { follow-up of the } \\
\text { LCP. }\end{array}$ & $\begin{array}{l}\text { Resident: This one is sometime next week, I'm going to learn } \\
\text { about imaging resources used to investigate dementia. So, } \\
\text { resources will be looking at past notes and then going to the } \\
\text { Internet, [name] library. Also asking supervisors if they know } \\
\text { of any good articles. And the challenges will just be having } \\
\text { enough time to do it. Identifiable results will be I'll be able to } \\
\text { answer what kinds of tests I would order given the case of } \\
\text { dementia or query dementia. } \\
\text { Supervisor: Okay. So, some other things you could look at are, } \\
\text { and if you remind me, there's guidelines for imaging. (E R3 S3) }\end{array}$ \\
\hline $\begin{array}{l}\text { Ensure resident } \\
\text { commitment }\end{array}$ & $\begin{array}{l}\text { Coach: } \\
\text { - uses LCP in a uniform } \\
\text { manner to determine } \\
\text { whether each of the } \\
\text { proposed changes has } \\
\text { the potential to be } \\
\text { adopted } \\
\text { - may have trainee } \\
\text { rehearse what would say } \\
\text { in certain instances (e.g. } \\
\text { to get feedback from a } \\
\text { peer that work is now } \\
\text { meeting standard or that } \\
\text { patient understands } \\
\text { what is being said) } \\
\text { - asks trainee if committed } \\
\text { to the change } \\
\text { Resident: } \\
\text { - articulates plan and } \\
\text { intentions in a clear } \\
\text { manner }\end{array}$ & $\begin{array}{l}\text { Coach: } \\
\text { - does not adopt the } \\
\text { LCP in a consistent } \\
\text { way } \\
\text { - misses steps } \\
\text { - allows changes that } \\
\text { are too broad or not } \\
\text { assessable } \\
\text { - does not consider } \\
\text { barriers that might } \\
\text { impact } \\
\text { implementing the } \\
\text { plan or ensure that } \\
\text { the plan is written } \\
\text { down so that it can } \\
\text { be retrieved }\end{array}$ & $\begin{array}{l}\text { Supervisor: Well, nice goal. Write down. Time management } \\
\text { clinic. Efficiency communication. And then with those } \\
\text { videos you can look if you succeeded [pause] because there } \\
\text { are practical issues, right, with which you can learn that, } \\
\text { open or closed questions. } \\
\text { Resident: Yes ... } \\
\text { Supervisor: Is it something that stands in the way? What } \\
\text { you suffer from? What you'd like to do something about? } \\
\text { Resident: Well I try to pay attention to it, or longer now, } \\
\text { and it has improved, but sometimes you ask something } \\
\text { and a surgery assistant has to ask three times, what are } \\
\text { you saying? (B R3 S1/2) }\end{array}$ \\
\hline $\begin{array}{l}\text { Follow-up of } \\
\text { goals }\end{array}$ & $\begin{array}{l}\text { Coach: } \\
\text { - reviews the LCP with the } \\
\text { trainee at the next }\end{array}$ & $\begin{array}{l}\text { Coach: } \\
\text { - makes vague or no } \\
\text { reference back to }\end{array}$ & $\begin{array}{l}\text { Supervisor: Now while we're talking about goals, I actually } \\
\ldots \text { We did look at this, and I think this already came up - } \\
\text { that seek opportunities for the IUD insertions. Checkmark. }\end{array}$ \\
\hline
\end{tabular}


Table 3 (Continued)

\begin{tabular}{|c|c|c|c|}
\hline Skill & $\begin{array}{l}\text { Description of skill used } \\
\text { effectively }\end{array}$ & $\begin{array}{l}\text { Description of skill } \\
\text { used less effectively }\end{array}$ & Exemplar quotations \\
\hline & $\begin{array}{l}\text { discussion [NB: In this } \\
\text { study, could only be } \\
\text { demonstrated for Time 2] }\end{array}$ & $\begin{array}{l}\text { LCP or progress } \\
\text { made from the last } \\
\text { discussion }\end{array}$ & $\begin{array}{l}\text { Good for you. And then you're just doing this but structure } \\
\text { presentation to preceptors and intentional hypothesis } \\
\text { development. Is that consciously in your mind or it just } \\
\text { happens now that it's almost unconscious? } \\
\text { Resident: If things get busy, sometimes I have to kind of take } \\
\text { a step back and kind of do that, be a little bit more mindful } \\
\text { and do that. But I think it's coming more naturally and it's } \\
\text { getting easier. And I ... In the past, I just would go in and see } \\
\text { a patient, and I wouldn't even think about kind of doing it. } \\
\text { But now I'm like, okay, I'm not in the right head space right } \\
\text { now, I'll take a second. Okay, let's go. [laughs] You know? So, } \\
\text { it's... At least I'm catching myself. } \\
\text { Supervisor: And that's a sign of a wise person. This is what I'm } \\
\text { actually trying to help my R1s [resident } 1 \mathrm{~s} \text { ] do sooner rather } \\
\text { than later. And you've got it. And for any of the teaching that } \\
\text { you're doing for my R1s in there, it's invaluable. Thank you } \\
\text { very much. And they really appreciate it. And they said back } \\
\text { to me how important it is for them to hear how you present. } \\
\text { And they're learning from that. Which is exactly how the } \\
\text { team room was designed to function. (A R3 s2) }\end{array}$ \\
\hline
\end{tabular}

ITERs, In-Training Evaluation Reports; IUD, intrauterine device; LCP, Learning Change Plan; C, location; R3, resident 3; S2, supervisor 2.

Table 4 Coaching micro skills and results in context of good supervisor communication promoting resident reflection and self-assessment

\begin{tabular}{|c|c|}
\hline Skill & Result \\
\hline $\begin{array}{l}\text { Providing feedback } \\
\text { or active listening }\end{array}$ & $\begin{array}{l}\text { Encouraged residents to describe } \\
\text { their perspectives about their data. } \\
\text { The tone of the conversation and } \\
\text { direction of the questions towards } \\
\text { an action plan were central to } \\
\text { resident acceptance }\end{array}$ \\
\hline $\begin{array}{l}\text { Using open-ended } \\
\text { questions }\end{array}$ & $\begin{array}{l}\text { Encouraged resident reflection on } \\
\text { their experiences and realistic } \\
\text { consideration of their external } \\
\text { performance data in light of } \\
\text { performance standards }\end{array}$ \\
\hline $\begin{array}{l}\text { Using clarifying } \\
\text { questions }\end{array}$ & $\begin{array}{l}\text { Promoted self-assessment that was } \\
\text { grounded in external data thereby } \\
\text { increasing the accuracy }{ }^{31}\end{array}$ \\
\hline
\end{tabular}

Focus on goal setting was a crucial component of the collaborative discussion. Often either the resident or the supervisor pushed the discussion towards specific aspects of goal setting, and this focus was facilitated by using an LCP that employed explicit strategies to articulate an assessable goal or goals. However, occasionally it appeared that supervisors failed to achieve a conversational, facilitative approach to the creation of the LCP and used it as a checklist to meet the requirements of the research study rather than as an authentic, useful strategy to facilitate goal setting. Failing to discuss specific, quantifiable goals minimised behavioural change as assessed in the second feedback session. Even if goals were discussed, the lack of a written LCP consistently impaired followup because it was not retrievable or goals were forgotten. Subsequent follow-up of the goals at the second session appeared to enhance accountability and successful goal achievement.

Finally, ensuring residents' commitment to the proposed goals was also helpful. This was not seen 
when supervisors unilaterally suggested gaps and goals, calling into question the effectiveness of goal development.

\section{Mapping and analysis}

In considering supervisors' use of individual coaching skills, three overarching themes emerged from the higher order analysis carried out during this stage. These were: (i) the interconnectedness of process and content; (ii) tension between encouraging self-direction and ensuring progression and competence; and (iii) the balance between a dialogue and a monologue.

\section{Interconnectedness of process and content}

Good process skills appeared to be required to elicit meaningful content needed to plan for change and learning. For example, less skilful supervisors were less likely to ask questions to promote reflection and seek the residents' views and more likely to provide advice. This led to less engaged residents who in turn were less likely (or sometimes not invited) to participate in co-development of goals and a plan. In this situation, even if they acquiesced to a supervisor-directed goal, they appeared generally less likely to follow through, as assessed in the second feedback session. Similarly, without utilising content to ground the discussion, it was difficult to identify meaningful goals and appropriate action plans. Process underpins content, whereas content is required to generate a meaningful discussion around significant, specific goals and their implementation.

\section{Tension between encouraging self-direction yet ensuring} progression to competence

When residents were performing at or above their expected level of competence, supervisors, although still promoting the necessity of establishing goals, appeared more likely to confirm the resident's goals and work with them to co-develop the action plan.

However, when residents appeared to be underperforming or unable to identify a goal, coaches almost uniformly, although still employing good process skills, explicitly directed the conversation towards gap areas. In these cases, they also prompted the resident to identify a goal and action plan, sometimes with multiple prompts, or identified them for the resident if he or she appeared unable. In the latter case, they would ask for the resident's agreement with what they had identified. It appeared that most coaches were able, in the moment, to diagnose the resident's level of competence and decide whether a facilitative or directive approach would be most appropriate.

\section{Balance between a dialogue and a monologue}

Many supervisors were able to establish a collaborative coaching dialogue using the communication micro skills to promote reflection, clarify the resident's understanding of both the content and context and co-develop the focus of the subsequent discussion and action plan. However, some supervisors, despite training, persisted solely in telling residents what they needed to know, identified performance gaps and provided extensive advice. In these cases, the conversation was essentially a monologue with minimal verification with the resident to ensure agreement with the proposed interpretation or to confirm commitment to the supervisor-established goals. Although increases in supervisor direction seemed to be required when residents were struggling, some supervisors persisted with this approach even with residents at expected competency levels. In these cases, when reviewing resident achievement of the goal and action plan in the follow-up feedback session(s), there appeared to be less completion. It appears that the trainee can ostensibly agree to the suggestions but ignore the suggested goals restricting opportunities for the development of self-confidence and self-efficacy in their path towards competence.

\section{DISCUSSION}

To the best of our knowledge, this is the first study to examine the individual skills used in medical education coaching in practice. This paper provides insights into the dynamics of coaching across five different residency programmes in three countries. It confirms the use of process and content coaching skills derived from the literature and identified overarching features of coaching: the interconnectedness of process and content; the tension that can occur between residents and supervisors as the residents strive for independence, and the importance of achieving a balance between dialogue and monologue in coaching conversations.

\section{Process and content coaching skills}

The R2C2 model includes a focus on the supervisor-resident relationship, the resident's reaction to their performance feedback and their understanding of the feedback content prior to 
initiating the final coaching phase. These three activities reflect process-oriented coaching skills we believe are integral to successful coaching. However, in this study, we were able to identify and expand the description of the skills that specifically underpin this coaching approach.

Preparation for coaching set the stage for effective discussion and included identifying and understanding not only the assessment materials but also the residents' current experience and future rotations. Awareness of the materials was consistently observed although understanding of the resident context was sometimes not evident. Preparation of the resident for the coaching experience was inconsistent and to enhance participation, it would be important to educate residents about the approach including the educational foundations that support coaching and outline the proposed enhancement of self-directed learning, self-reflection and the journey to competence. ${ }^{24}$

Relationship development was almost universally demonstrated. Training for the R2C2 study and providing sample facilitative statements may have assisted this skill. ${ }^{24}$ Although good coaching relationships were not dependent on previous interaction in this study, once within the coaching dyad, the development of a longitudinal relationship was identified as a crucial component of a successful coaching experience, a finding supported by other studies. ${ }^{11,35,36}$ This may be one of the most challenging differences between medical education coaching and coaching in other settings. Watling et al., ${ }^{37}$ found that physicians who were familiar with both medical education and sports and medicine coaching noted that the length of the relationship in these non-medical settings provided more opportunities to develop trust which impacted the perceived appropriateness, accuracy and intent of the feedback allowing more specific and critical feedback to be delivered and integrated. They noted that the more sporadic nature of relationships makes this less attainable in the current medical education environment.

We also identified micro skills in the coaching sessions that reflect good communication and promote reflection and self-assessment. ${ }^{38}$ These skills appeared to be more challenging for some supervisors. Supervisors also may be limited in their ability to address resident needs by fears of hurting residents' feelings or damaging self-esteem ${ }^{14}$ and by institutional cultures of politeness and assumed excellence in which language that is potentially damaging to the resident is discouraged. ${ }^{12}$ It may be helpful to provide more intensive training to develop competent use of these micro skills. Similarly, providing a better grounding in these micro skills may enhance supervisor flexibility allowing them to pivot the discussion towards crucial, emergent issues when appropriate.

Content-oriented skills were also important in ensuring the feedback was clearly presented and understood prior to collaborative discussion of performance gaps, goal setting and development of a set of specific, achievable goals that could be subsequently monitored in follow-up. Developing specific achievable goals and action plans were instrumental in making the identified improvement. ${ }^{39}$

\section{Interconnectedness of process and content}

The importance of the interconnectedness between process and content skills, highlighted in this study, supports findings from earlier research that has looked at the various skills as independent or combined. All of the skills are important and can be described as interconnected in a tango-like manner, ${ }^{40}$ and it is the combination of skills in the context of the particular needs of the resident that yields the best outcomes. The need to develop and foster a relationship based on trust and credibility is a process skill important in underpinning the successful implementation of the remaining coaching skills. ${ }^{5,9,11,40-43}$ A trusting relationship enables an open discussion that supports development and leads to an action plan. Without trust, it is difficult to help a resident progress and achieve their goals. This relationship, or educational alliance, ${ }^{10,11}$ is judged by residents based upon the supervisor's engagement as an educator, a positive and supportive attitude and commitment to promoting residents' growth. The educational alliance not only affects a resident's engagement with a particular piece of feedback at the moment of delivery, but also has consequences for future engagement with (or avoidance of) further learning interactions with supervisors. ${ }^{11}$

\section{Self-direction versus ensuring progression to competence}

Tension between self-direction and progression is a critical factor in CBME as residents strive to achieve milestones and complete Entrustable Professional Activities. It is a natural consequence of the environments in which training occurs as the resident works towards becoming an independent 
practitioner and the supervisor assesses the progress the resident is making towards independence and safe practice. The need to ensure safe practice differs in a significant way from the sports, music and business environments where achievements are individually oriented with little or no impact on the safety or well-being of others. Such tension has been found in other studies ${ }^{14,17,44}$ and speaks to the importance of guiding residents as well as also supporting their progressive independence.

Cultivating a resident's understanding of the crucial role of accurate self-assessment as part of a selfregulating profession is an important outcome. ${ }^{38}$ Residents need to have an opportunity to self-assess their performance and progression using external data, describe their own perspectives about their data and feedback and provide opportunities for informed self-assessment. They need opportunities to discuss the development of their goals and action plan as they work towards competency. Equally important is recognising when the resident's perspectives may be limited due to, for example, their own experiences and lack of opportunities to observe others and to realistically consider their external performance data in light of performance standards. Exploring the mismatch between selfassessment and external data requires communication skill and sensitivity.

A long-term goal of coaching in education is to cultivate self-assessment skills and promote lifelong learning. Coaching empowers residents to monitor their progression and recognise when to seek external guidance. $^{21,45}$

\section{Dialogue versus monologue}

Achieving a balance in the discussion with residents between coaching and pre-emptively identifying the goals and actions independent of the resident is challenging for supervisors and has been noted in other coaching contexts. ${ }^{21,46}$ Although facilitative versus directive feedback techniques have been found to be more helpful, ${ }^{47}$ it can be tempting for supervisors to distrust residents' ability to identify appropriate goals, often based on the limitations posed by inaccurate self-assessment. ${ }^{14}$ This limitation becomes less problematic when external data is provided, discussed and understood prior to discussing goals and next steps. However, in this study, despite providing both the data and the opportunity to understand and apply the data, ${ }^{48-51}$ some residents appeared unable or unwilling to translate the discussion into developing an action plan. In this case, supervisors may need to take a more directive approach. Several supervisors in this study demonstrated flexibility in determining when the shift between self-direction and guided goal setting was required without sacrificing resident buyin. Creating a medical culture where feedback and coaching for change are recognised as important and expected to occur, appears critical in this work. ${ }^{12,40}$

In summary, we learned from this study that coaching requires using specific process- and content-oriented skills identified in the literature, and that supervisors in residency education can apply these skills in feedback and coaching sessions with residents. Using them effectively to develop a respectful learner-centered environment and to codevelop with the resident a plan for learning and change arising from the feedback, can result in the development of explicit plans for change and implementation of those plans. Our earlier paper ${ }^{24}$ reported enhanced resident engagement in the feedback and planning processes, reduction of feelings of defensiveness or of feeling unsupported, and general reduction of identified barriers to effective feedback.

This study adds to that earlier work by identifying and describing the specific coaching skills required to achieve these outcomes, and how the skills are used. However, incorporating these skills into existing approaches also creates challenges for programmes, supervisors and residents. For programmes, attention to creating an appropriate culture of openness and expectation of feedback is crucial. Faculty development is needed both to establish the baseline knowledge and skills for coaching as well as longitudinally to ensure the skills have been maintained. We learned particularly that using open, facilitative communication skills is not intuitive and will require practice and reinforcement. Putting processes in place for developing, tracking and reviewing action plans appeared to be of crucial importance. Supervisor challenges include mastering the tensions between process- and content-oriented skills, self-direction and progression and coaching and telling. Residents too require orientation to coaching strategies, especially those who may struggle to accept feedback and to view coaching as positive supportive activities, which promotes them developing competence.

This study has limitations. This study included only 15 dyads and further examination in other settings would be helpful. Although we were able to see the variability in how supervisors approached coaching from our analysis of coaching within the R2C2 
model, it is possible that training supervisors to use the model in other settings might uncover nuances we did not discover.

\section{Future research and directions}

It is not known whether these approaches could be adopted for shorter sessions with residents, for example, at the end of a day in the operating room or emergency medicine shift or after a patient visit in an ambulatory setting. The model needs to be examined for use in briefer encounters where the goal is to encourage the resident to think about their most recent workplace experience and consider how they might get better results with a different approach. Similarly, in these settings, supervisors would need to consider how they might follow up when they next work with the resident.

\section{CONCLUSIONS}

This study provides a comprehensive overview of process- and content-oriented skills supervisors use for effective coaching. Furthermore, it demonstrates the importance of attending to both process and content and related skills when coaching; they are interconnected and both are required to ensure optimal coaching. We also identified the importance of mastering the tension between encouraging selfdirection and ensuring progression to competence. Further, supervisors need to attend to the balance between a coaching discussion or dialogue and a more typical didactic teaching approach and the circumstances in which a shift may be required.

Contributors: HA, MGZ, JS, KDK and JML made substantial contributions to study conception and design and data acquisition. HA, MGZ, JML and JS made substantial contributions to analysis and interpretation of the data. HA and JML made substantial contributions to drafting the document. HA, MGZ, JS, KDK and JML made substantial contributions to critically revising the article. All authors (HA, MGZ, JS, KDK and JML) approved the final manuscript for submission.

Acknowledgements: we are grateful to Michelle Boudreau (Dalhousie University) who served as the research associate.

Funding: National Board of Medical Examiners: Stemmler Grant, 2014-16.

Conflicts of interest: the authors declare that they have no competing interests.

Ethical approval: the Dalhousie University Health Science Research Ethics Board approved the proposal on July 18, 2014 (REB\# 2014-3301). The University of Calgary
Conjoint Health Research Ethics Board approved the proposal on July 29, 2014 (REB\# 14-1180).

\section{REFERENCES}

1 Watling C, LaDonna KA, Lingard L, Voyer S, Hatala R. 'Sometimes the work just needs to be done': sociocultural influences on direct observation in medical training. Med Educ 2016;50 (10):1054-64.

2 LaDonna KA, Hatala R, Lingard L, Voyer S, Watling C. Staging a performance: learners' perceptions about direct observation during residency. Med Educ 2017;51 (5):498-510.

3 Sargeant J, Lockyer J, Mann K et al. Facilitated reflective performance feedback: developing an evidence- and theory-based model that builds relationship, explores reactions and content, and coaches for performance change (R2C2). Acad Med 2015;90 (12):1698-706.

4 Lovell B. What do we know about coaching in medical education? A literature review. Med Educ 2018;52 (4):376-90.

5 Sonesh SC, Coultas CW, Lacerenza CN, Marlow SL, Benishek LE, Salas E. The power of coaching: a metaanalytic investigation. Coaching 2015;8 (2):73-95.

6 Alken A, Tan E, Luursema J-M, Fluit C, van Goor H. Coaching during a trauma surgery team training: perceptions versus structured observations. Am J Surg 2015;209 (1):163-9.

7 Gagnon LH, Abbasi N. Systematic review of randomized controlled trials on the role of coaching in surgery to improve learner outcomes. Am J Surg 2018;216 (1):140-6.

8 Könings KD, van Berlo J, Koopmans R, Hoogland H, Spanjers IA, ten Haaf JA, van der Vleuten CP, van Merriënboer JJ. Using a smartphone app and coaching group sessions to promote residents' reflection in the workplace. Acad Med 2016;91 (3):365-70.

9 Watling C, Driessen E, van der Vleuten CPM, Vanstone M, Lingard L. Music lessons: revealing medicine's learning culture through a comparison with that of music. Med Educ 2013;47 (8):842-50.

10 Telio S, Ajjawi R, Regehr G. The, "Educational Alliance" as a framework for reconceptualizing feedback in medical education. Acad Med 2015;90 (5):609-14.

11 Telio S, Regehr G, Ajjawi R. Feedback and the educational alliance: examining credibility judgements and their consequences. Med Educ 2016;50 (9):933-42.

12 Ramani S, Konings KD, Mann KV, Pisarski EE, van der Vleuten CPM. About politeness, face, and feedback: exploring resident and faculty perceptions of how institutional feedback culture influences feedback practices. Acad Med 2018;93 (9): 1348-58. 
13 Graddy R, Wright S. On the value of coaching in medicine. Acad Med 2016;91 (8):1037.

14 Ramani S, Könings KD, Ginsburg S, van der Vleuten CPM. Twelve tips to promote a feedback culture with a growth mind-set: swinging the feedback pendulum from recipes to relationships. Med Teach 2018; 1-7. [Epub ahead of print.]

15 Ginsburg S, Vleuten C, Eva KW, Lingard L. Hedging to save face: a linguistic analysis of written comments on in-training evaluation reports. Adv Health Sci Educ 2015;21 (1):175-88.

16 Teunissen PW, Stapel DA, van der Vleuten C, Scherpbier A, Boor K, Scheele F. Who wants feedback? An investigation of the variables influencing residents' feedback-seeking behavior in relation to night shifts. Acad Med 2009;84 (7):910-7.

17 Mann K, van der Vleuten C, Eva K, Armson H, Chesluk B, Dornan T, Holmboe E, Lockyer J, Loney E, Sargeant J. Tensions in informed self-assessment: how the desire for feedback and reticence to collect and use it can conflict. Acad Med 2011;86 (9):1120-7.

18 Delva D, Sargeant J, Miller S, Holland J, Alexiadis Brown P, Leblanc C, Lightfoot K, Mann K. Encouraging residents to seek feedback. Med Teach 2013;35 (12):e1625-31.

19 Ramani S, Post SE, Könings K, Mann K, Katz JT, van der Vleuten C. "It's Just Not the Culture": a qualitative study exploring residents' perceptions of the impact of institutional culture on feedback. Teach Learn Med 2017;29 (2):153-61.

20 Van Nieuwerburgh C, ed. Coaching in Education: Getting Better Results for Students, Educators, and Parents. London: Karnac Books 2012;222.

21 Van Nieuwerburgh C. An Introduction to Coaching Skills: A Practical Guide, 2nd edn. London, UK: SAGE Publications Ltd 2017;232.

22 Van de Ridder JM, Stokking KM, McGaghie WC, ten Cate O. What is feedback in clinical education? Med Educ 2008;42 (2):189-97.

23 Boud D, Molloy E. Rethinking models of feedback for learning: the challenge of design. Assess Eval High Educ 2013;38 (6):698-712.

24 Sargeant J, Lockyer JM, Mann K et al. The R2C2 model in residency education: how does it foster coaching and promotoe feedback use? Acad Med 2018;93 (7):1055-63.

25 Norcini J, Burch V. Workplace-based assessment as an educational tool: AMEE Guide No. 31. Med Teach 2007;29 (9):855-71.

26 Miller A, Archer J. Impact of workplace based assessment on doctors' education and performance: a systematic review. BMJ 2010;341:c5064.

27 Driessen E, Scheele F. What is wrong with assessment in postgraduate training? Lessons from clinical practice and educational research. Med Teach 2013;35 (7):569-74.

28 Ritchie J, Spencer L. Qualitative analysis for applied policy research. In: Bryman A, Burgess RG, eds. Analyzing Qualitative Data. London, UK: Routledge 1994;173-94.
29 Gale NK, Heath G, Cameron E, Rashid S, Redwood S. Using the framework method for the analysis of qualitative data in multi-disciplinary health research. BMC Med Res Methodol 2013;13 (1):117.

30 Ward D, Furber C, Tierney S, Swallow V. Using framework analysis in nursing research: a worked example. J Adv Nurs 2013;69 (11):2423-31.

31 Urquhart LM, Ker JS, Rees C. Exploring the influence of context on feedback at medical school: a video-ethnography study. Adv Health Sci Educ Theory Pract 2018;23 (1):159-86.

32 Kuper A, Lingard L, Levinson W. Critically appraising qualitative research. BMJ 2008;337:a1035.

33 Liamputtong P. Qualitative Research Methods, 3rd edn. Victoria, Australia: Oxford University Press 2009.

34 Spence GB, Oades LG. Coaching with selfdetermination in mind: using theory to advance evidence-based coaching practice. Int J Evid Based Coach Mentor 2011;9 (2):37-55.

35 Haidet P, Stein HF. The role of the student-teacher relationship in the formation of physicians. $J$ Gen Intern Med 2006;21 (1):16-20.

36 Walters L, Prideaux D, Worley P, Greenhill J. Demonstrating the value of longitudinal integrated placements to general practice preceptors. Med Educ 2011;45 (5):455-63.

37 Watling C, Driessen E, van der Vleuten CPM, Lingard L. Learning culture and feedback: an international study of medical athletes and musicians. Med Educ 2014;48 (7):713-23.

38 Sargeant J, Eva KW, Armson H, Chesluk B, Dornan T, Holmboe E, Lockyer JM, Loney E, Mann KV, van der Vleuten CP. Features of assessment learners use to make informed self-assessments of clinical performance. Med Educ 2011;45 (6): 636-47.

39 Reed S, Lockspeiser T, Burke A, Gifford K, Hanson J, Mahan J, McKenna M, Rosenberg A, Li ST. Practical suggestions for the creation and use of meaningful learning goals in graduate medical education. Acad Pediatr 2016;16 (1):20-4.

40 Bing-You R, Varaklis K, Hayes V, Trowbridge R, Kemp H, McKelvy D. The feedback Tango: an integrative review and analysis of the content of the teacherlearner feedback exchange. Acad Med 2018;93 (4):657-63.

41 Bing-You RG, Hayes V, Varaklis K, Trowbridge R, Kemp H, McKelvy D. Feedback for learners in medical education: what is known? A scoping review Acad Med 2017;92 (9):1346-54.

42 Ives Y. What is 'coaching'? An exploration of conflicting paradigms. Int J Evid Based Coach Mentor 2008;6 (2):100-13.

43 Grant AM. Autonomy support, relationship satisfaction and goal focus in the coach-coachee relationship: which best predicts coaching success? Coaching 2014;7 (1):18-38.

44 Kennedy TJT, Regehr G, Baker GR, Lingard LA. 'It's a cultural expectation...' The pressure on medical 
trainees to work independently in clinical practice. Med Educ 2009;43 (7):645-53.

45 Weinstein DF. Feedback in clinical education:untying the gordian knot. Acad Med 2015;90 (5):559-61.

46 Stanier M. The Coaching Habit: Say Less, Ask More and Change the Way You Lead Forever. Toronto, ON: Box of Crayons Press 2016.

47 Archer J. State of the science in health professional education: effective feedback. Med Educ 2010;44 (1):101-8.

48 Watling C. Unfulfilled promise, untapped potential: feedback at the crossroads. Med Teach 2014;36 (8):692-7.
49 Jinks D, Dexter J. What do you really want: an examination of the pursuit of goal setting in coaching. Int J Evid Based Coach Mentor 2012;10 (2):100-10.

50 Armatas A. Suggestive techniques in coaching. Coaching 2011;4 (1):32-41.

51 Drake DB. What do coaches need to know? Using the Mastery Window to assess and develop expertise Coaching 2011;4 (2):138-55.

Received 26 July 2018; editorial comments to authors 26 September 2018; accepted for publication 9 January 2019 